\title{
THE CONSTRUCTION COMMON PRODUCT CODING SYSTEM
}

\author{
Nai-Hsin Pan \\ Dept of Construction Engineering, National Yunlin University of Science and Technology, \\ 123, Section 3, University Rd. Douliu, Taiwan, e-mail: pannh@yuntech.edu.tw \\ Received 22 Sept 2008; accepted 24 Mar 2009
}

\begin{abstract}
The primary technological barrier in effectively transferring information automatically and adopting Auto ID/EDI technologies in construction is the lack of a construction common product coding system (CCPCS) for encoding and transferring information. To facilitate the information transfer between different components of the construction process and using new Auto ID technologies in construction application, the paper proposes a construction common product coding system (CCPCS). It is a set of agreed-upon standards that will facilitate communication among parties in the construction process especially using automated data collection processes and possibly technologies to transfer information in electronic form. The CCPCS the paper proposed can be classified as internal or external, permanent or temporary, primary or secondary etc. The research use barcode technology and EDI as the primary technologies to explore the impact of the CCPCS in construction application. However, the concepts of CCPCS still are advantageous for the applications of other Auto ID technologies individually or integration in construction.
\end{abstract}

Keywords: common product code, construction industry, Auto ID.

\section{Introduction}

While field supervisors may spend $30-50 \%$ of their time recording and analyzing actual performance data, thus, the lack of project management information and control system often limits the effectiveness of the project management (Kiziltas, Akinci 2005). During past years, industry has witnessed a dramatic transformation in electronic data generation and management. The transition from single mainframe computers to multitudes of minicomputers and microcomputers has significantly altered the manner and means by which owners and contractors might manage construction-related data. Automatic data processing systems have been in use for over 15 years in manufacturing and retail industries. Today there is a number of distinct Auto ID Technologies in use. The principal Auto ID approaches are bar codes, optical character recognition (OCR), radio frequency identification (RFID), magnetic stripe, voice recognition, and electronic data interchange (EDI). Although these technologies have found wide usage in some industrial sectors, they have not been adopted to any large extent in the construction industry. Because of the variance between different industries, it is not obvious that new technologies can be directly adopted in the construction industry without considerable study and research. The benefits of using these new technologies, such as bar code, RFID and EDI, have already been recognized in other industries, but have only found some limited specialized usage in the construction industry. Song (2005), Song et al. (2006) proposed an automated tracking of materials approach by which materials tagged with radio frequency identification (RFID) tags, which prove the approach can improve project performance and enable effortless derivation of project performance indicators. Ghanem, AbdelRazig (2006) proposed a model based on Radio Frequency Identification (RFID) system which can keep track of the material used on site, based on the estimated quantity will permit making a better estimate of the amount of work done on a construction site. Jaselskis, El-Misalami (2003) proposed applying the radio frequency identification (RFID) technology in construction operations, which can enhance the efficiency of information management for construction industry owners and contractors. Lauth, Papanicolaou (2008) developed a tracing technique for sand particles focusing on using artificial coarse sand particles and a Radio Frequency Identification (RFID) system. Brilakis, Soibelman (2005) proposed an approach which can automatically identify shapes, objects and materials from the image content, through direct and indirect methodologies has enabled the development of several civil engineering-related applications that assist in the design, construction and maintenance of construction projects. Referring to other industries implemented experiences, there is no reason that construction industry could not benefit from applying those technologies in construction process like other industries have done. Kong et al. (2004) have developed e-union framework for unifying B2B e-trading in marketplace to solve the problem of tedious efforts to search in different e-trading portals. Hadikusumot et al. (2005) proposed a decentralized database system equipped with electronic agents for material procurement. Sacks et al. (2005) have thoroughly investigated the feasibility of automatically tracking the location of construction resource (labourers and equipment) and 
identifying and determining the status of the basic activity that the resource is engaged in. Hadikusumot et al. (2005) proposed a decentralized database system equipped with electronic agents for material procurement.

Automotive, health care, textile, defense, and other industries have begun industry-wide implementation of some principal technologies for automatic data capture. These industries have found that the full benefits of Auto ID technologies are only achievable through development of common product coding system (CPCS) for information transfer. CPCS provides a common means of communication between customers and suppliers. Without CPCS, the Auto ID technologies' capabilities would be limited. Besides, the Auto ID (e.g. bar coding), standard numbering also is integral to an EDI concept. To be most effective, EDI requires the sender and receiver of EDI transactions to use the same standard product numbers. Unique customer numbers for common materials in the construction also make implementation of EDI difficult. Benefits of EDI include accuracy, cycle time reduction, and elimination of clerical costs involved in transcribing documents and key entering product catalogue, purchase orders, invoices, and other transactions into computer systems.

For engineering contractors and facility owners, who develop integrated materials management computer systems, Auto ID technologies will provide an effective enhancement that will improve data transmission time and accuracy, and, perhaps, more important, drastically reduce paper handling requirements. The construction industry can benefit from studying the approaches used by other industries in developing construction common product coding system (CCPCS) for information transfer.

An approach for improving information flow or access involves performing translations or format modifications on the data such as the data can be transferred to different environments. These transfers typically occur between contractor and material suppliers. However, the information transfer raises many related questions pertaining to establish a construction common product coding system (CCPCS).

A typical construction project involves the transfer of data between a wide scope of contracting entities such as architect/engineer, owner, subcontractors and material suppliers. It is more efficient to transfer data in an electronic format as opposed to a written format, especially, when the data can be processed automatically upon receipt without human intervention.

During recent years, because of a growing understanding of the computer's advantage for managing construction operations, there are more and more contractors using microcomputers right at the jobsite. Combined with Auto ID technologies' capabilities, project data could be transferred electronically among the different parties (A/E, contractor, subcontractors, supplier) without being remanufactured (rekeying, reformat, interpreting). Furthermore, the data transferred among the trading parties could be paperless without human intervention. It is important to realize that there can be significant benefits, which can be derived from the use of a computer system with Auto ID technology implementation to perform traditional materials management. In a construction context, an integrated materials management computer system is one that effectively links the design interface, requisitioning, purchasing, expediting, receiving, payment and warehousing materials functions. Auto ID technologies can actually extend the capabilities of the integrated materials management system by providing external automation linkages between entities.

The CCPCS is a set of agreed-upon standards that will facilitate communication among parties in the construction process especially using automated data collection processes and possibly technologies to transfer data by using an electronic form. At the present time there is a lack of comprehensive data standards in the construction industry and such standards are not used substantially in the overall construction industry. In recent years, some of the larger construction companies have been willing to use Auto ID technologies in the construction operation but most of these activities are limited to internal applications. To facilitate the automated information transfer or information collection which could be used for any construction operation and the encouragement of the use of computerized data processing technology in the construction industry, it is necessary to develop the CCPCS carefully targeted.

For example, from a materials management standpoint, purchasing and control of materials on a construction project is major undertaking. One of the components of this problems dilemma is encountered when ordering parts from different vendors. There are very few universal part number standards available to order materials (Gibson 1990) in the construction industry.

Similarly, materials management transactions in this area are also very difficult and usually require the use of expert buying knowledge. There are literally millions of different items which may need to be ordered for a construction job and there are many equivalent product items that can be ordered. Most large engineering contractor organizations support an internal material part number database with as many as 20-30,000 different part numbers. Maintaining a cross-referencing database of part numbers between contractor and supplier is difficult, but must be undertaken by one of the two parties in order to place orders. The results of this process are inefficiencies, errors, and higher costs in purchasing.

At present, the industrial process pipe and fitting industry is working to establish standard product identification numbers (SPINS) for items considered by the industry to be of a commodity nature. These efforts are being conducted by the American Supply Association Industrial Piping Distributors (IPD) SPIN Task Force and its Industry Bar Code Alliance.

The need for established industry standard product numbering schemes was first recognized in many industries when bar codes were being placed on their product lines. For example, the electrical materials industry has adopted a two-part, eleven digit numbers to identify a product and its manufacturer. The first part is a six digit manufacturer's identification number assigned by the 
Uniform Code Council (UCC) and the second part is a five digit item or product number assigned by the manufacturer (National Electrical Manufacturers Association 1987). In the following chapters, the research will discuss in more detail information transfer standard possibilities for the construction industry,

In construction, MasterFormat (CSI 1995) is widely used as an information classification system (ICS), but is not applicable to construction product management. Kang and Paulson (1997, 1998) suggested a construction information classification system (CICS) with five facets of classification, including facility, space, element, operation, and resource. Rad (1999) showed three bases for the work breakdown structure (WBS): deliverable oriented, schedule oriented, and resource oriented. Hanlon and Sanvido (1995) established a construction information model to classify constructability information and facilitate improvement of processes and products. Chang, Tsai (2003) establishes an engineering information classification system (EICS) for engineering work to facilitate information sharing throughout the planning, design, construction, and maintenance phases of a construction project. Until now there has been no ICS or coding system for the purpose above, which perhaps is less tangible and more difficult to categorize and standardize than construction product.

The overall objective of this research is to propose a construction common product coding system (CCPCS) for improving the electronic data transfer in the construction industry. Of particular interest is the use of electronic data collection technologies to accomplish this transfer and to identify current barriers to the adoption of improved transfer of information which is external to particular firms and which needs to be standardized. Ideally, the improved methods of data transfer should eliminate the need for re-keying data, reduce data entry errors, and result in the smooth transfer of data from one company to another company. Therefore, the following sections will analyze the information type in CCPCS.

\section{Information in External/Internal System}

The UPC experience shows us that this kind of information in external systems must be Industry-Standardized. Based on the scenario above, the information needed to be collected in a Material Management System (Table 1) is examined. The "Application" indicates the information in the column of "Information to be collected" which is used for "external" or "internal".

For example, Product ID number, Manufacturer ID number, Vendor ID number, Serial number, etc. belong to the group of "External".

Information in an internal system is used for the company's operation itself. This information is of limited use for the other companies who may not have an identical data structure in their management system. This application of information is defined as "Internal". Using Table 1 as an example, Job number, Project number, BOM number, Labor information, and etc. belong to the group of "Internal". The company can "do its own thing" for this kind of application information.
Table 1. Information type analysis of s CCPCS

\begin{tabular}{|c|c|c|c|}
\hline Class & Data type & $\begin{array}{c}\text { Applica- } \\
\text { tion }\end{array}$ & Information to be collected \\
\hline \multirow[t]{9}{*}{ Date/Time } & Temporary & External & Site need date \\
\hline & Temporary & External & Vendor ship date \\
\hline & Temporary & External & Vendor drawing approval date \\
\hline & Temporary & External & PO award date \\
\hline & Temporary & External & MRP to purchasing date \\
\hline & Temporary & External & Bid due date \\
\hline & Temporary & External & RFQ date \\
\hline & Temporary & External & MRQ to purchasing date \\
\hline & Temporary & External & Lead time \\
\hline \multirow[t]{6}{*}{ Quantity } & Temporary & Internal & Required quantity \\
\hline & Temporary & Internal & Requisitioned quantity \\
\hline & Temporary & External & Purchased quantity \\
\hline & Temporary & External & Received quantity \\
\hline & Temporary & Internal & Inventory on hand quantity \\
\hline & Temporary & Internal & Shortage quantity \\
\hline \multirow{6}{*}{$\begin{array}{l}\text { Size } \\
\text { (dimension) }\end{array}$} & Temporary & External & Length \\
\hline & Temporary & External & Width \\
\hline & Temporary & External & Height, Depth, Thickness \\
\hline & Temporary & External & Diameter, Radius \\
\hline & Temporary & External & Areas \\
\hline & Temporary & External & Volume \\
\hline \multirow{6}{*}{$\begin{array}{l}\text { Weight/ } \\
\text { Cost }\end{array}$} & Temporary & External & Material Unit Cost \\
\hline & Permanent & External & Material/Building Component ID \\
\hline & Permanent & External & Package Indicator \\
\hline & Permanent & External & Unit of Measure \\
\hline & Permanent & External & $\begin{array}{l}\text { Rare Material/Building Compo- } \\
\text { nent/Accessory ID }\end{array}$ \\
\hline & Permanent & External & $\begin{array}{l}\text { Specification ID(Color, Material } \\
\text { test standard, size, etc.) }\end{array}$ \\
\hline \multirow[t]{9}{*}{ Object } & Permanent & External & Architect ID \\
\hline & Permanent & External & Contractor ID \\
\hline & Permanent & External & Manufacturer ID/Vendor ID \\
\hline & Permanent & External & Owner \\
\hline & Temporary & Internal & labor \\
\hline & Period & External & Serial Number \\
\hline & Period & External & Serial Shipping Pack Number \\
\hline & Temporary & Internal & Project Number \\
\hline & Temporary & Internal & Job Number \\
\hline \multirow[t]{5}{*}{ Document } & Temporary & External & Drawing Number \\
\hline & Temporary & External & PO number \\
\hline & Temporary & External & RFQ number \\
\hline & Temporary & External & Quotation number \\
\hline & Temporary & Internal & BOM number \\
\hline \multirow[t]{5}{*}{ Location } & Permanent & External & Ship(Deliver) to location code \\
\hline & Permanent & External & Bill(Invoice) to location code \\
\hline & Permanent & External & $\begin{array}{l}\text { Ship(Deliver) to Postal Code } \\
\text { within the single Postal Authority }\end{array}$ \\
\hline & Permanent & External & $\begin{array}{l}\text { Ship(Deliver) to Postal Code } \\
\text { within 3-digit ISO Country Code } \\
\text { Prefix }\end{array}$ \\
\hline & Temporary & Internal & $\begin{array}{l}\text { Location, Warehouse, Shelf for } \\
\text { Inventory }\end{array}$ \\
\hline
\end{tabular}

There is no need to "Industry-Standardize" this type of information except to the extent that some type of standard would be beneficial in establishing uniform accounting and in fostering the development of "off-theshelf" software which might be developed by software vendors for internal operations. The development of a 
broad-scale market for such software could reduce software costs and improve reliability in much the way that mass markets for spread sheets or word processing has done.

\section{Information type and standard making}

When the construction industry considers standardizing the information in the construction process, it is necessary to analyze the characteristics of the information types. Based on this objective, the information involved in the construction process could be categorized into three data types: Temporary, Periodical, and Permanent. They will be explained detailed in the following by using the table as an example.

Temporary. This type of data need to be collected in the construction process is variable based on the particular application situation. For example, in Table 1, the information such as "Site need date" is for the product required date in the working site, "Quantity of Receiving" for the quantity of product receiving in the site, Project number, and Drawing number, etc. all are the groups of temporary data type. When the cooperation relationship of the trading partners is over, this kind of information will no longer be of use, when the situation changes (e.g. project or specific job is done). Therefore, this kind of information could be defined as "Temporary". This information is needed for temporary operation. Most of them are used for recording keeping among the trading partners. For the use of EDI, bar code system, it is necessary to define the data format and application indicator.

Periodical. This type of data involved in the construction process needs to be kept for a period and may exceed the time length of a job, but does not need to be permanently archived. For example, the time period may be one month, one year, or ten years, etc. depending on the applied objects. The difference between the periodical and temporary is that this type of data will not change for different situations, for example, different projects, jobs, location, trading parties, In Table 1 Serial Shipping Pack Code, which could be used in material management of the construction process to help a receiving clerk get more detailed information about the content of a particular single object or pack containing several objects during shipping, in addition to the basic product information. Every specific single item or pack of items in a shipment from a supplier will be assigned a unique number for the use of tracking. This type of information is only necessary to be maintained until those identified items are received on the job and the shipping make-up information will be no longer needed. Examples may be the shelf life of a particular object, the date a prefabricated component is due, or expiration date of a particular product item. Compared with the first type of data, this type of data will necessarily have to be maintained for a longer time. However, this information will not be needed at some cut-off point. Therefore, this kind of information could be defined as "Periodical". Like a previous type, it is necessary to define the data format and application indicator. For example, serial number is a typical example of this type of information. With the standardization of this type of information, the supplier could attach a unique number to identify or tracking a specific object which is ready to ship the receiver. Also, the user could use this serial number in their internal operation.

Permanent. Compared the previous type of data, the third type of information must be maintained indefinitely. In Table 1, Standard Commodity ID number, Manufacturer ID number, Vendor ID number, Package Indicator, and Ship (Deliver) to Postal Codes, etc, belongs to this data type. For example, Standard Commodity ID number is used to indicate the construction item instead of using an arbitrary description. This number indicates a kind of construction material or item whose specification, size will not change from one firm to another firm. This number remains constant. Manufacturer ID number is used to identify the specific manufacturer instead of encoding a whole manufacturer's name, especially in Auto ID/EDI applications. Every manufacturer supplying materials to the construction industry should be assigned a unique number in addition to assigning unique numbers to all other permanent participants in the construction process. Like the Standard Product ID number, this number remains constant. Therefore, this kind of information could be defined as "Permanent". For the use of EDI and bar code applications, standardization of this type of information not only defines its data format and application indicator but also assigns and maintains a unique number by the construction industry group. For example, Supplier ID number is one of the typical examples.

Standardizing the information to be collected in construction will enhance the communication among the trading parities (suppliers, owner, designer, contractor) whether using Auto ID technologies are used or not. However, as previously indicated it is probably not possible to standardize all information in construction, at least in any near term. For example, some information to be collected in construction management is for temporary use, like "project name". Then, what information could be the primary target to be standardized?

When the target application is defined, the user may need to know all information rather than just the product identification itself in order to get the whole story. This information could be classified into "primary information" and "secondary information". For example, in the material control application, when a field office receives the material, they not only identify the material itself as the "primary information" but also have to know the quantity, purchase order number, serial number, and so on as the "secondary information".

This secondary information requirement will be different in different applications. This information also needs to be defined with respect to consideration such as the fixed length of codes and the code structure, much like developing Standard construction product ID Code numbers.

If the code number is too long or variable, it is possible for users to ignore a digit or to get the wrong digit which will result in an incorrect product being requested and shipped. Especially, when a computerized application 
is involved, the long, varying length and significant number requires more complex system design. A resulting difficulty in this type of use of bar codes will require a very large space to print the long bar code symbol and could result in more scanning and errors. Therefore, standardized coding should preferably be fixed, and an adequate length of numbers should be used, which will be much easier to handle in computer systems.

After analyzing the information type of the CCPCS, the paper examined the information elements in the process of material receiving and verifying to develop a suggested approach for industry-standardization.

\section{The CCPCS's structure}

In materials and component management application, the objective of the study is to build the CCPCS for construction material and engineering component identification standard numbering system.

In order to develop such a system, firstly, there is a need to identify the object identification (primary information) in this particular application. In material and components identification numbering system, the suggested primary information will be shown in the following Table 2.

Table 2. The suggested primary information attribute

\begin{tabular}{l|c|c}
\hline \multicolumn{1}{c|}{ Primary identification } & $\begin{array}{c}\text { Data } \\
\text { identifier }\end{array}$ & $\begin{array}{c}\text { Length } \\
\text { of digit }\end{array}$ \\
\hline Basic material identification & $\mathrm{P}$ & 12 \\
\hline Intermediate pack identification & $\mathrm{P}$ & 14 \\
\hline Organization identification number & $\mathrm{O}$ & 8 \\
\hline
\end{tabular}

Basic material identification. As an initial proposition, the material and component identification numbering system is proposed to use 12 digits to identify the "basic material identification number". A "basic material identification number", or commodity code, is the lowest level of identification for a given material or component. This "basic" identification will uniquely identify any item related to construction. A basic material identification number can be divided into three parts structured in Fig. 1.

The first part consists of two digits, which are data identifiers. Data identifiers are simple prefixes in codes that indicate the contents of the code to follow. In bar code applications, data identifiers are usually the first piece of code in a bar code and they are used to tell what the rest of the code is supposed to identify. For instance, in the following example, " $P$ " is the data identifiers which indicate that the following code is a commodity material identification number for the construction industry.

The second part consists of three digits, which is a material group identification number. A material group ID number may be the first part of the code and prefixes other information in the codes that classify the items of the code to follow. For example, "032" might indicate the item which belongs to the field "Concrete Reinforcement -Related" and "151" indicate the item belonging to the field "Pipe fitting "Related" using the Masterformat categorization. This is primarily of value to humans examining the code as a computer database can be randomly queried.

The third part consists of seven digits which is material identification number. A material ID number is used building on the concept of common commodity codes to differentiate the material or component item of same group. For example, in material group ID number "032" which represents "Concrete Reinforcement", "1070250" indicate "Reinforced Steel \#8 ASTM A615 Grade 60", and "1070200" indicate "Reinforcing Steel \#5 ASTM A615 Grade 60".

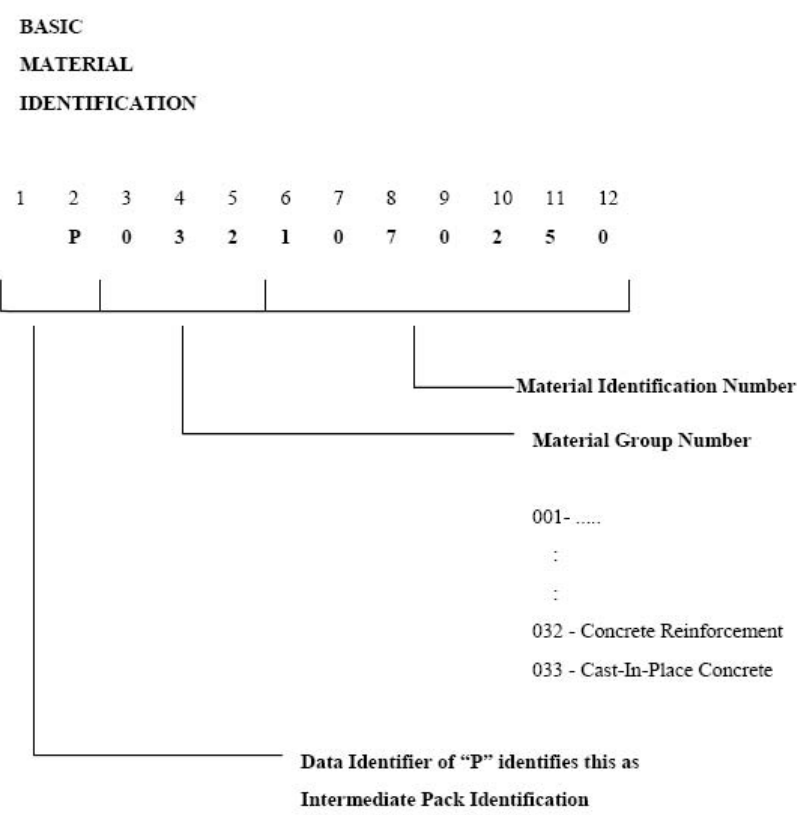

Fig. 1. BASIC MATERIAL IDENTIFICATION coding structure

The product ID number is extremely useful for the communication among the trading parties of the construction process in the Auto ID/EDI based MMS. That means it is for external use. Also, this standard product code will be unique and constant (or at least for a long period). Like SPIN for the piping and fitting industry, the construction material/component identification code needs to be defined and maintained by an organization representing the construction industry in the same way that the IBCA does. This number is used "permanent" in external systems. It is necessary to industry-standardize.

Intermediate pack identification. When identical material units are packaged into a standard quantities or intermediate packs or shipping containers, the material standard identification numbering system should specifies that they should be assigned a new, 14 digit number. For example, cases containing 12 pieces of reinforced bars would be assigned a different 14 digit number than cases containing 24 pieces of the same reinforced bars. The example will be shown in Fig. 2. First, using two digits in the front of intermediate packs, identification number indicates data identifier. Second, adding two additional digits which is "package level indicators" to 
the left of the basic material identification number creates a new 14 digit code identifies intermediate packs and shipping containers holding standard configurement of material or component unit.

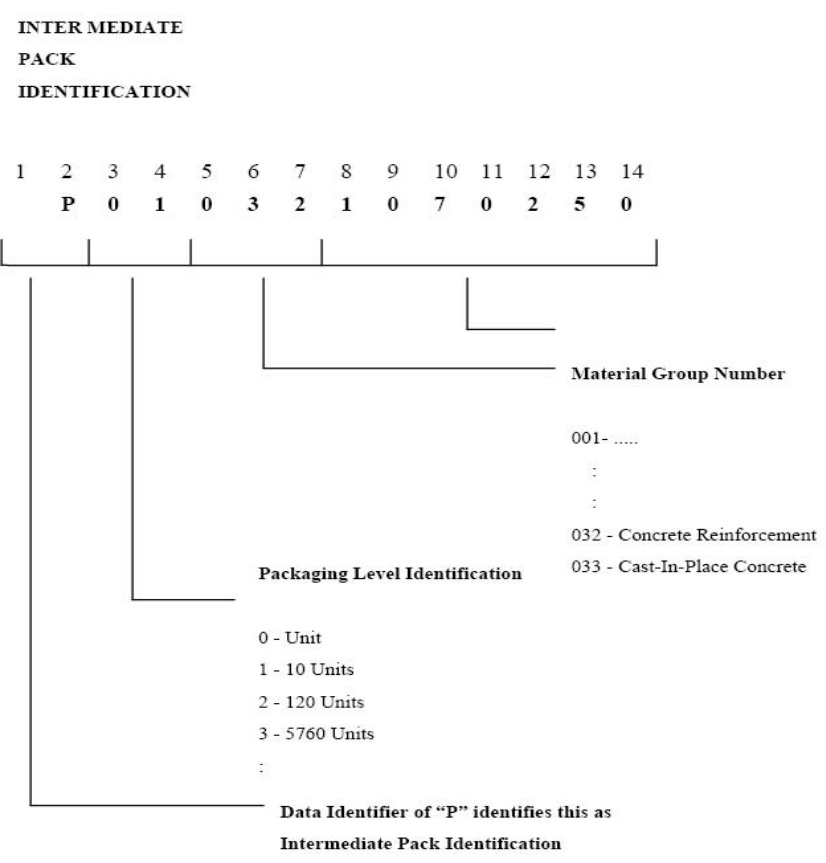

Fig. 2. INTERMEDIATE PACK IDENTIFICATION coding structure

Organizational ID number. The organizations directly involved in the construction material procurement could be basically grouped into architects/engineer, general contractors, subcontractors, owner, supplier, and manufacturers. Based on the concept of industry-wide information transfer standard, each organization should be assigned by a unique number for identification. This number should be unique among the different firms, just like a social security number is unique among persons. Like standard product ID number as primary information, the identification should be fixed with an adequate length of numbers to encompass all organizations involved in construction. Through a quantitative analysis, an adequate number of digits could be determined. For example, there are probably at least 2 million designers, 2 million contractors, 10 million vendors, 10 million manufacturers, and about 1 million companies who are interested in the standard assignment in construction(data above could got from the each representation organization in the construction standard committee). Therefore, there is totally about 25 millions organization needed to be assigned a unique number. An 8 digit number could provide 100 million capacity which is enough to encompass the range of organizations involved in the construction industry. The example will be shown in Fig. 3. Like UPC from the retail industry, the specific organization identification code needs to be assigned and maintained by a "standard" committee representing the construction industry in the same way that the Uniform Code Council (UCC) represents the retail industry. Every organization involved in the construction should be assigned a unique number by construction "standard" committee. Attaching two digits of data identifiers in the front indicate the content of the following code. In the following example, application identifier of "O" identifies the following code as Organizational Identification Code. The following 8 digit unique number is assigned and maintained by the "construction industry standard committee" to represent a particular organization for the construction industry. In a few cases an organization may already have an UPC identifier or other identifier and these numbers could be cross-referenced to the construction identifier.

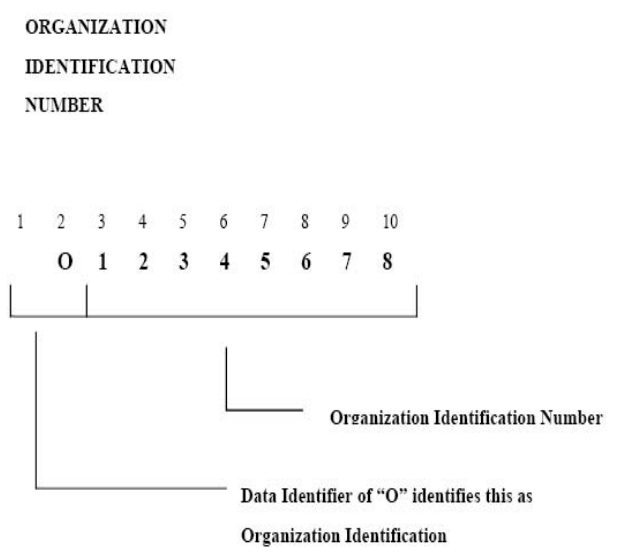

Fig. 3. ORGANIZATION IDENTIFICATION NUMBER coding structure

Identify the application identification (secondary information) in the material receiving and verifying process application. The secondary information requirement will be different for different applications but must have a mechanism for accessing such information within the standardized fixed length universal code structures. The problem is much like developing a Standard Product ID Code number. The standardization for the secondary information could be defined as"Application Standard". In material and components identification numbering system, the suggested application standard in this application will be shown in Table 3 .

Table 3. The suggested secondary information attribute

\begin{tabular}{l|c|c}
\hline \multicolumn{1}{c|}{ Secondary Information } & Data Identifier & Length of Digit \\
\hline Serial Shipping Pack Code & $1 \mathrm{~S}$ & 15 \\
\hline Purchase Order Number & $\mathrm{K}$ & 8 \\
\hline Quantity(Actual Weight) & $2 \mathrm{Q}$ & 5 \\
\hline Quantity(Actual Length) & $1 \mathrm{Q}$ & 5 \\
\hline Quantity(Pieces) & $\mathrm{Q}$ & 5 \\
\hline Carrier ID Number & CI & 5 \\
\hline
\end{tabular}

Serial Shipping Pack Code. The serial shipping pack code is a shipment-related code. It is primarily intended for situations where multiple products are put into single pack or containers for shipment (mixed merchandise containers). The serial shipping pack code is the equivalent of a license plate identifying each individual pack (or shrink wrapped pallet). Like a license plate, each pack must have a unique number. Uniqueness could be 
created by using the manufacturer number plus a sequential unique number assigned by the manufacturer and adding data identifier in the front. For example, the serial shipping pack number " $1 \mathrm{~S} 413242111003121$ " in the following example, the first 2 digits " $1 \mathrm{~S}$ " indicates data identifiers which represent "Serial Shipping Pack Code", the next 8 digits identify the specific manufacturer (organization) and the rest of 7 digits are assigned by this specific manufacturer itself for internal application. The example will be shown in Fig. 4. This number is periodical for external use.

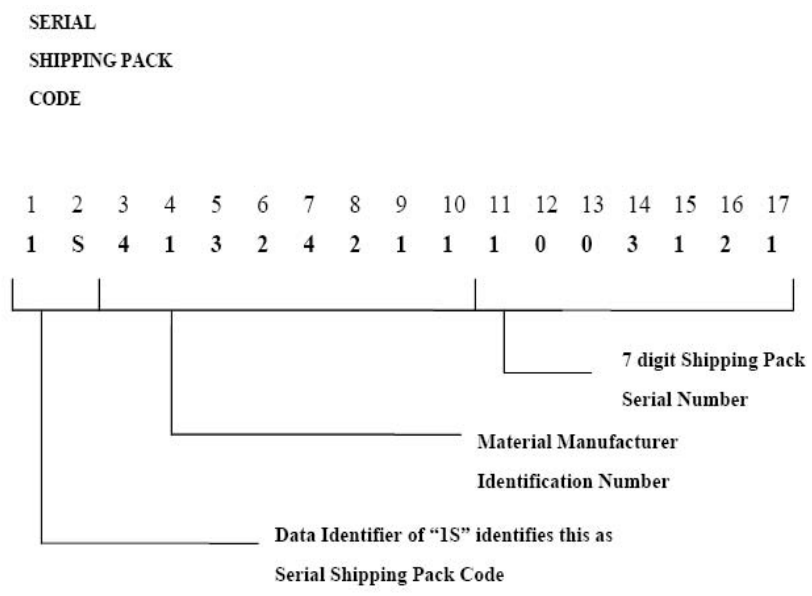

Fig. 4. SERIAL SHIPPING PACK CODE coding structure

Purchase Order (PO) number. This number helps the MMS, the accounting department and supplier tracks the requisition material from the PO document. Some companies would like to automate their receiving function as much as possible, but either they or their suppliers may not be ready to implement EDI. In this situation, one of the alternatives is for suppliers to bar code customer purchase order numbers on shipping labels. This enables the receiving clerks to scan the bar code to retrieve a record of the purchase order from the computer. Then, the shipment contents can be matched to the original purchase order to automate the receiving process. This number is temporary for external use. The purchase order number is assigned by the customer and added a data identifier in the front. In the following example, the length of the purchase order number is 8 digits, plus the data identifiers (K) in the front. The example will be shown in Fig. 5.

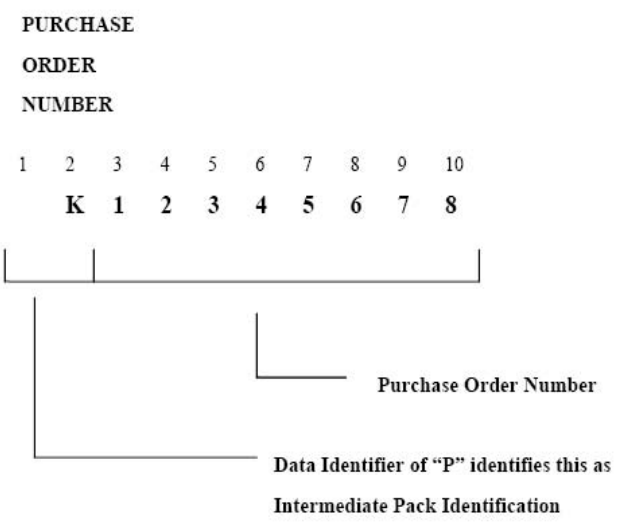

Fig. 5. PURCHASE ORDER NUMBER coding structure
Quantity (actual weight). This number provides this shipping information of quantity related to the actual weight. This number is assigned by the supplier and added a data identifier. In the following example, the length of the number is 5 digits, plus the data identifier (2Q). This number is temporary for external use. The example will be shown in Fig. 6 .

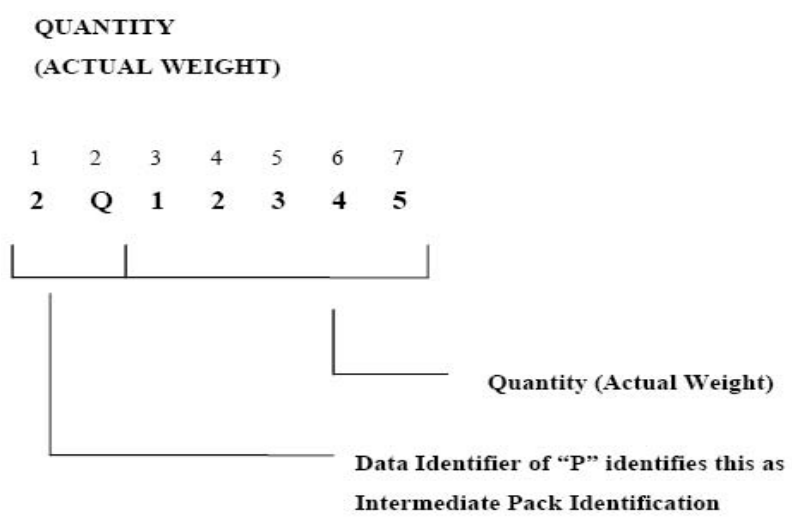

Fig. 6. QUANTITY (ACTUAL WEIGHT) coding structure

Quantity (actual length). This number provides this shipping information of quantity related to the actual length. This number is assigned by the supplier and added a data identifier. In the following example, the length of the number is 5 digits, plus the data identifier (1Q). This number is temporary for external use. The example will be shown in Fig. 7.

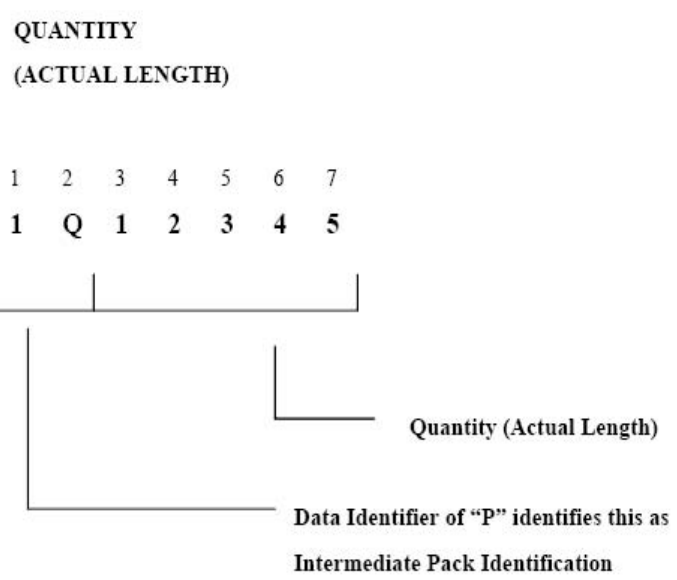

Fig. 7. QUANTITY (ACTUAL LENGTH) coding structure

Quantity (pieces). This number provides this shipping information of quantity related to the actual pieces. It is assigned by the supplier and added a data identifier. In the following example, the length of the number is 5 digits, plus the data identifier (Q). This number is temporary for external use. The example will be shown in Fig. 8. 


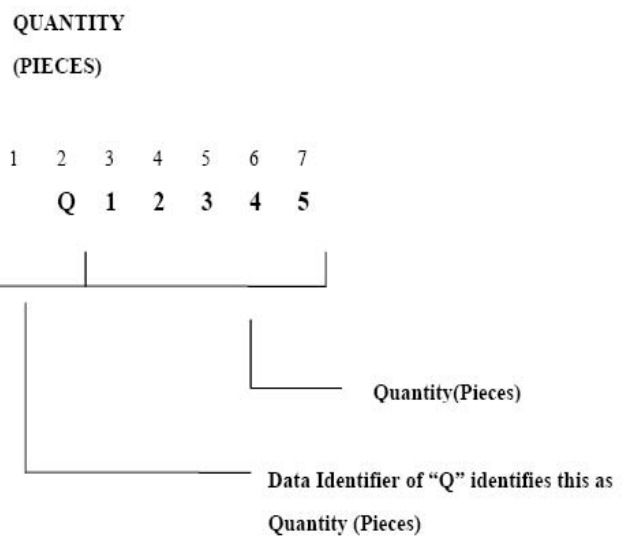

Fig. 8. QUANTITY (PIECES) coding structure

Carrier Identification. This number provides the information that is responsible for transporting this shipping. This number is assigned by supplier or Transportation company and added by a data identifier. In the following example, the length of the number is 5 digit, plus 2 digit data identifier (CI). This number is temporary for external use. The example will be shown in Fig. 9.

\section{CARRIER \\ IDENTIFICATION}

$\begin{array}{lllllll}1 & 2 & 3 & 4 & 5 & 6 & 7\end{array}$

C

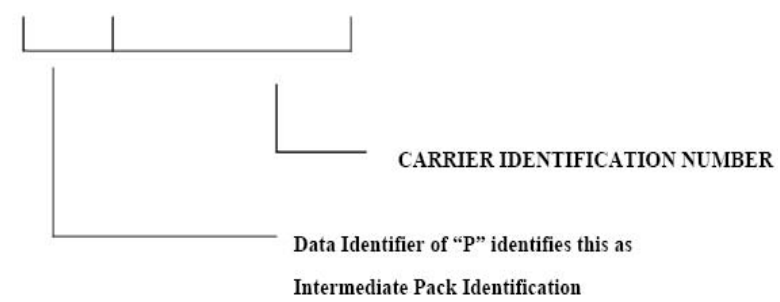

Fig. 9. CARRIER IDENTIFICATION coding structure

\section{The suggested CCPCS development procedure for construction application}

Some industries traditionally use customer assigned part number. For example, automobile manufacturers typically engineer components and require suppliers to use the buyer's part numbers. The same has been true for Department of Defense suppliers, who are required to use the National Stock Number. However, for common materials sold to many different customers, this practice results in higher costs due to unique labeling for each customer and complex systems to maintain cross-references to each customer's numbers. These costs must be passed on to the customer. As the result of growing recognition of the costs and complexity, the construction industries should consider acceptance of Industry-wide Standard Product ID code number for the common suppliers. Therefore, the Industry Standard Coding scheme should be standardized to maximize the benefits of bar coding.

Auto ID/EDI has been implemented successfully in industries rather than in the construction industry. The construction industry could also benefits from Auto ID/EDI by referring to the successfully implementation experience from other industries. Although there are a few firms in the construction industry which have implemented Auto ID/EDI in localized level, the construction industry still lags behind the automotive, retail grocery, and other industries in the widespread use of Auto ID/EDI technology. One of the major barriers is lack of the CCPCS. Based on the Auto ID/EDI based computerized MMS, described above, the role of the CCPCS in the construction application can be identified. The areas in materials management which could benefit from the CCPCS include:

- Information Transfer;

- Material Receiving;

- Inventory Control;

- Material Tracking;

- Project Control;

- Finance Control;

- Auto ID/EDI support.

The need for the concept of the CCPCS in various segments of construction industry disciplines has been recognized. A number of industry associations are working to develop common commodity codes. SPIN for the piping, fitting, and valve industry developed by IBCA could be a good example. In the construction industry, directly using the classification system of MASTERFORMAT to identify construction material products would not be adequate. The approach of using MATERFORMAT by CSI to provide a systematic method to categorize the groups of construction materials and building components in the construction industry could be a starting point.

To facilitate Auto ID/EDI implementation in the construction industry, there is undoubtedly a necessity to develop a CCPCS. To formulate a construction industry standard, a project group which represents the construction industry needs to be established. The major objective of this project group is not only formulating a industrywide standard but also facilitating Auto ID/EDI technologies in the construction industry. Therefore, the members of the project group should come from different fields which could provide the related technology and information in the construction industry standard making and Auto ID/EDI technologies. For example, AIM could provide the Auto ID/EDI technology support and standard (e.g. bar code standard). ASTM could provide the specification standard for construction material which could help identify what information needed to be specified in the material identification. AGC which represent the contractors in the construction industry could help identify what external information needed to be collected and standardized in the construction process.

The next step is to study the approach of standard development from the other industries instead of "reinvent the wheel". For example, the UPC system developed by UCC which represents the grocery industry identifies the common product with national "manufacturerspecific" standard number. SPIN developed by IBCA provide a concept of common commodity code identifying the common product with the standard number. 
An application in the field of the material management could be a trial project. Materials are introduced in the early stages of the construction cycle, are highly visible to many users, and are common to the fabrication, distributor, shipper, and user. Because the acquisition and installation of construction materials involves suppliers, contractors, and owners, a target application in materials management allows existing "intra-company" standards to be integrated in the development of industry-wide "inter-company" standards.

Then, it is necessary to analyze the information type. The information for "External" application also with "Permanent" data type should be the first priority to industry standardizes, for example, material/component identification, organization (manufacturer, supplier, designer/engineer, and contractor) identification.

The research use barcode technology and EDI as the primary technologies to explore the impact of the CCPCS in the construction process. However, the concepts of industry standard still are advantageous for the applications of other Auto ID technologies individually or integration in construction.

The highly fragmented nature of the construction industry makes it extremely difficult to achieve uniform action. This exaggerated because there was no single focus in the federal government for construction. One result has been a tendency to micro-optimize problems or to develop progress in a particular sector for which there is a champion group or agency. In view of the fact that as much as $25 \%$ of construction may involve public funds. It would seem that government could play an important role in improving efficiency through information definition and transfer.

\section{Conclusion}

1. The primary technological barrier in effectively adopting Auto ID/EDI technologies in construction is the lack of the CCPCS for encoding and transferring information.

2. The complex nature of construction and the vast number of items which go into construction creates severe difficulties in developing an all-encompassing information identification system.

3. It is concluded that the use of a data identifier along with permanent identification numbers for all participate would provide the most effective solution.

4. Information for construction work can be classified as internal or external, permanent or temporary, primary or secondary etc. It is only mandatory that external information could be industry standardized although standardization of other information could encourage the development of a supporting software industry which could increase accuracy and reduce costs.

\section{Reference}

Brilakis, I.; Soibelman, L. 2005. Image processing techniques for identification of materials from construction site images, in Proc of Conference Computing in Civil Engineering, 12-15 July 2005, Cancun, Mexico. 8 p.
Chang, A. S.-T.; Tsai, Y.-W. 2003. Engineering information classification system, Journal of Construction Engineering and Management 129(4): 454-460. doi:10.1061/(ASCE)0733-9364(2003)129:4(454)

Ghanem, A. G.; AbdelRazig, Y. A. 2006. A Framework for real-time construction project progress tracking, in Proc of the 10th Biennial International Conference on Engineering, Construction, and Operations in Challenging Environments (Earth \& Space 2006) and 2nd NASA ARO/ASCE Workshop on Granular Materials in Lunar and Martian, 5-8 March, 2006, Houston, USA: 1-8.

Gibson, G. 1990. Data Integration and Transfer Methodologies in Industrial Construction, PhD thesis, Auburn University, USA.

Hadikusumot, B. H. W.; Petchpong, S.; Charoenngam, C. 2005. Construction material procurement using internet-based agent system, Automation in Construction 14(6): 736749. doi:10.1016/j.autcon.2005.01.004

Hanlon, E. J.; Sanvido, V. E. 1995. Constructability information classification scheme, Journal of Construction Engineering and Management 121(4): 337-345.

doi:10.1061/(ASCE)0733-9364(1995)121:4(337)

Jaselskis, E. J.; El-Misalami, T. 2003. Implementing radio frequency identification in the construction process, Journal of Construction Engineering and Management 129(6): 680-688

doi:10.1061/(ASCE)0733-9364(2003)129:6(680)

Kang, L. S.; Paulson, B. C. 1997. Adaptability of information classification systems for civil works, Journal of Construction Engineering and Management 123(4): 419-426. doi:10.1061/(ASCE)0733-9364(1997)123:4(419)

Kang, L. S.; Paulson, B. C. 1998. Information management to integrate cost and schedule for civil engineering projects, Journal of Construction Engineering and Management 124(5): 381-389.

doi:10.1061/(ASCE)0733-9364(1998)124:5(381)

Kiziltas, S.; Akinci, B. 2005. The need for prompt schedule update by utilizing reality capture technologies: a case study, in Proc of Construction Research Congress, April 5-7, 2005, San Diego, USA: 163-167.

Kong, S.; Li, H.; Hung, T.; Shi, J.; Castro-Lacouture, D.; Skibniewski, M. 2004. Enabling information sharing between e-commerce systems for construction material procurement, Automation in Construction 13(2): 261-276. doi:10.1016/j.autcon.2003.08.011

Lauth, T. J.; Papanicolaou, A. N. 2008. Experimental/feasibility study of radio frequency tracers for monitoring sediment transport and scour around bridges, in Proc of the World Environmental \& Water Resources Congress, May 12-16, 2008, Honolulu, USA: 1-10.

Rad, P. F. 1999. Advocating a deliverable-oriented work breakdown structure, Cost Engineering 41(12): 35-39.

Sacks, R.; Navon, R.; Brodetskaia, I.; Shapira, A. 2005. Feasibility of automated monitoring of lifting equipment in support of project control, Journal of Construction Engineering and Management 131(5): 604-614. doi:10.1061/(ASCE)0733-9364(2005)131:5(604)

Song, J. 2005. Tracking the Location of Materials on Construction Projects. PhD thesis, University of Texas at Austin, USA.

Song, J.; Haas, C. T.; Caldas, C.; Ergen, E.; Akinci, B. 2006. Automating the task of tracking the delivery and receipt of fabricated pipe spools in industrial projects, Automation in Construction 15(2): 166-177.

doi:10.1016/j.autcon.2005.03.001 


\section{BENDROJO STATYBOS PRODUKTO KODAVIMO SISTEMA}

\section{N.-H. Pan}

\section{S a n tra k a}

Viena iš pirmujų kliūčių perkeliant informaciją ir taikant Auto ID/EDI technologijas statyboje yra bendrojo statybos produkto kodavimo sistemos (CCPCS) trūkumas. Ja galima užkoduoti ir perkelti informaciją. Norint palengvinti skirtingu statybos proceso elementų informacijos perdavimą ir pritaikyti statybai naujas Auto ID technologijas, straipsnyje buvo pasiūlyta bendrojo statybos produkto kodavimo sistema (CCPCS). CCPCS yra rinkinys nustatytų standartu, kurie palengvins statybos proceso dalyvių bendravima, ypač naudojant automatinius duomenų rinkimo procesus ir technologijas, kurios paverstų informaciją elektronine forma. Siūloma CCPCS gali būti skirstoma i̇ išorinę, vidinę, laikinają ir pastoviaja, pirminę, antrinę ir t. t. Tyrime naudojama brūkšninio kodo technologija ir EDI, kaip pirminès technologijos, kuriomis nustatomas CCPCS taikymo statyboje poveikis. CCPCS koncepcija vis dar yra naudinga taikant Auto ID technologijas tiek individualiai, tiek integruojant ị statyba.

Reikšminiai žodžiai: bendrojo produkto kodas, statybos pramonè, Auto ID.

Dr. Nai-Hsin PAN is Associate Professor in the Department of Construction Engineering at National Yunlin University of Science and Technology, Taiwan. He is a member of supply chain council. Also, he is a corporate member of Chartered Institute of Housing Asian Pacific Branch. His research interests include dynamic simulation applications in construction, construction materials management, and artificial intelligence applications in construction. 